\title{
LUSTRA IMAGOLOGICZNE MICKIEWICZA
}

\author{
Michat KuZIaK ${ }^{1}$ \\ (Uniwersytet Warszawski)
}

Słowa kluczowe: Mickiewicz, romantyzm, imagologia
Key words: Mickiewicz, romanticism, imagology

Abstrakt: Michał Kuziak, LUSTRA IMAGOLOGICZNE MICKIEWICZA. „PORÓWNANIA” 20, 2017. T. XX, S. 39-52. ISSN 1733-165X. Artykuł poświęcony jest Mickiewiczowskiemu dyskursowi imagologicznemu. Służył on poecie do konstruowania projektów - tak związanych z kulturą oraz literaturą, jak i szerzej: tożsamościowych, odnoszących się do wizji Polski i Słowiańszczyzny. Dyskurs ten ma charakter zmienny i heterogeniczny. Stanowi nie tylko odbicie romantycznego myślenia o narodzie i narodowości, ale i świadectwo wynajdywania tradycji narodowej w sytuacji opresji, zagrożenia egzystencji narodu pozbawionego państwa.

Abstract: Michał Kuziak, MICKIEWICZ'S IMAGOLOGICAL MIRRORS. "PORÓWNANIA" 20, 2017. Vol. XX, P. 39-52. ISSN 1733-165X. The article discusses Mickiewicz's imagological discourse. It served to construct projects related to culture and literature and more broadly to the identity relating to the vision of Poland and Slavia. This discourse is changing and heterogeneous. It involves not only a reflection of the romantic thinking about the nation and nationalities but also the testimony of inventing national traditions under oppression, threats of nation deprived of state existence.

Nowoczesna imagologia po lekcji poststrukturalizmu buduje swoją metodę w opozycji do stanowiących jedno z jej źródeł XIX-wiecznych koncepcji romantycznych, które operowały kategorią ducha narodowego. Podkreśla się, że przedmiotem badań imagologii jest dzisiaj nie tyle charakter narodowy - traktowany w bardziej (duch) lub mniej (historia) wyraźny sposób jako formuła esencjalistyczna, istotny aspekt antropologii, odciskający piętno na myśleniu o kulturze, języku i literaturze, a także na filologii narodowej i literaturoznawstwie porównawczym - ile wyobrażenia, tekstowe reprezentacje tego, jak postrzegane są inne narody. Ujęcie to odda-

1 E-mail: michalkuziak@wp.pl 
la obiekcje René Welleka dotyczące imagologii, jej podejrzanego statusu w obrębie komparatystyki (Wellek 394).

Zmiana taka zaowocowała interdyscyplinarnymi ujęciami krytycznymi i dekonstrukcyjnymi, które między innymi odsłaniają mechanizmy - tak to ujmę - retoryki/perswazji narodowości, konstruktywistyczny aspekt pojęcia "narodowości" (wpisującego się w pole ideologii i władzy), a także związanych z nim praktyk stereotypizacji. Badaniom tego typu patronowały książki Ernesta Gellnera, Benedicta Andersona czy Erica Habsbawma i Terence'a Rangera (Gellner; Anderson; Hobsbawm, Ranger). Owa zmiana wiodła ponadto do kwestionowania - ostrożniej mówiąc naruszania czy może przemieszczania - kategorii różnicy, fundamentalnej w XIX-wiecznym wytwarzaniu indywidualnych narodowych tożsamości i w konsekwencji do akcentowania ponadnarodowej cyrkulacji idei, obrazów, dyskursów odznaczających się intertekstualnym charakterem (Leersen 2007).

Oczywiste jest, że tłem tych przemian są tak zmiany w nowoczesnej teorii literatury i kultury, jak i procesy kulturowe, związane z tendencjami globalizacyjnymi i wielokulturowością. Sprawa jest wszakże bardziej skomplikowana - myślę choćby o narodach wyłaniających się w XX wieku (kwestię tę akcentuje krytyka postkolonialna, zob. Fanon), a także o odżywających nacjonalizmach, które możemy właśnie obserwować, a które zdają się przeczyć tezie o końcu epoki tożsamości narodowych.

Moim zamiarem jest wszakże powrót do wieku XIX, do pytań stawianych wówczas $w$ perspektywie tożsamościowej, choć zarazem, nie ukrywam, celem jest też pokazanie skomplikowania dawanych na nie odpowiedzi - skrywanego, ale i ujawnianego przez interesujący mnie tu romantyczny dyskurs narodowości, ujawniający się w refleksji imagologicznej. Zagadnienie, które mnie zajmuje, ma swoją polską specyfikę, wynikającą $\mathrm{z}$ historycznego doświadczenia narodu pozbawionego państwa, sytuowanego na peryferiach cywilizacji europejskiej wobec kształtujących swoje formuły narodowości potęg imperialnych i zarazem ciągle pamiętającego o czasach własnej świetności. Jak zauważa Grażyna Królikiewicz, istnieje różnica między polskim a europejskim romantycznym myśleniem o narodowości. Podczas gdy w drugim przypadku (badaczka przywołuje przykład Francji) „narodowość” znaczy tyle co "państwo", ,"społeczeństwo”, w pierwszym wiąże się z dążeniem do odsłonięcia prawdy o duchu narodowym, spajającym przeszłość i przyszłość (Królikiewicz 77). Inny aspekt specyfiki kształtowania się polskiej formuły narodowości, pominięty tu przeze mnie, to napięcia związane z powstawaniem nowoczesnego narodu, dotyczące podziałów stanowych, widoczne zwłaszcza w drugiej połowie XIX wieku.

Twórczość Adama Mickiewicza powstaje w czasach, w których kształtuje się nowoczesny dyskurs narodowości i nowoczesne rozumienie narodu, a co za tym następuje - ważne staje się doświadczanie Innego jako innego narodowo (Kuziak 2007). Zestawienie tekstów Mickiewicza filomaty z tekstami Mickiewicza z lat 
trzydziestych i czterdziestych (w przypadku tych drugich, co kiedyś opisałem, kolejna zmiana dokonuje się w obrębie jednego tekstu - prelekcji paryskich, zob. Kuziak 1999) pozwala dostrzec, tak to ujmę, niestabilny charakter konstruowanego przez autora Pana Tadeusza pojęcia „narodowości”. Ta niestabilność oddaje, jak sądzę, nie tylko specyfikę nowoczesnego wynajdywania tradycji narodowej, ale w szczególny sposób wiąże się z niestabilnością przedmiotu - polskiej narodowości. Z wielu powodów pozostającego, mimo że poświęcono mu w różnych dyskursach dużo miejsca, swego rodzaju work in progress, na co wpływa w szczególny sposób, jak już wspomniałem, sytuacja narodu pozbawionego państwa. Akcentuję tę kwestię, myśląc o najnowszej książce Przemysława Czaplińskiego, w której wyeksponowane zostaje zjawisko poruszenia polskiej mapy imagologicznej, obserwowane dzisiaj przez badacza (Czapliński). Otóż, jak chcę pokazać, mapa ta nigdy nie była stała.

Pytanie, które stawiam, dotyczy tego, jak Mickiewicz wytwarza polski dyskurs narodowości. Można by zakwestionować tę konstruktywistyczną formułę wytwarzania (czy wynajdywania), argumentując, że jest ona obca świadomości romantyka, że myśli on w kategoriach esencjalizmu. Ewentualnie osłabić radykalność owej formuły - zwracając uwagę na to, że jego wyobrażenia o narodowości i poszczególnych narodach kształtowały się na przestrzeni wielu lat, w zmiennych okolicznościach. Wspomniana obcość nie jest według mnie jednak tak oczywista choćby w związku ze wspomnianym wyżej procesem przepracowywania i dopracowywania rozumienia narodowości polskiej i słowiańskiej przez poetę. Tym, na co chcę zwrócić szczególną uwagę, jest fundamentalne znaczenie w owej praktyce imagologii - pozwalającej formować rozumienie narodowości w procesie różnicowania i utożsamień, dającej lustro, w którym mogą przejrzeć się Polacy/Słowianie, konfrontując z nim swoją tożsamość czy właśnie: wytwarzając, wynajdując ją. Przedmiotem mojego zainteresowania będą tu wypowiedzi Mickiewicza poświęcone literaturze, kulturze oraz historii (Krasuski 19 i n.).

\section{Tożsamość i różnica}

Punkt wyjścia Mickiewiczowskiego dyskursu narodowości zdaje się uniwersalistyczny, wyraźnie naznaczony duchem oświecenia, choć, wypada dodać, w myśli filomatów widoczne jest także stopniowo rosnące zainteresowanie odrębnością narodową i specyfiką narodowości polskiej, manifestujące się w zwrocie ku historii ojczystej (Witkowska 1998: 191 i n.). Przypomnę tu wiersz Do Joachima Lelewela, traktujący o uniwersalnej tożsamości europejskiej, w którą wpisują się tożsamości lokalne. Wiersz przynosi zarazem wizję historii kształtowanej przez różne narody. Dokonuje się to wszakże pod uniwersalnym "słońcem Prawdy", w równy sposób przyświecającym poszczególnym nacjom: 
A słońce Prawdy wschodu nie zna i zachodu,

Równie chętne każdego plemionom narodu,

I dzień lubiące każdej rozszerzać ojczyźnie,

Wszystkie ziemie i ludy poczyta za bliźnie.

Stąd, kto się w przenajświętszych licach jej zacieka,

Musi sobie zostawić czystą treść człowieka [...].

(Mickiewicz I: 95)

Wizja zróżnicowanego narodowo świata zostaje wyeksponowana przez poetę w Przemowie do Ballad i romansów; ujęcie takie jest umocowane w przekonaniu o istnieniu różnicy kulturowej wytwarzanej przez geografię (klimat to istotna dla romantycznej imagologii kategoria wprowadzona już przez Monteskiusza) i historię, na którą Mickiewicz będzie zwracał szczególną uwagę. Poeta w następujących słowach określa swój zamiar historycznoliteracki:

Aby zaś pokazać dowodnie, jak rodzaj poezji romantycznym zwany powstał, doskonalił się i na udzielny, w sobie skończony ukształcił się nareszcie, potrzeba wyłącznych okoliczności wpływających nań, czyli tworzących go szukać i odróżniać między mnóstwem innych okoliczności, tworzących inne poezji rodzaje. Należy poszukiwać zwyczajnej zawisłości i następstwa zdarzeń, jak za odmianą uczuć, charakteru, opinii narodowych zachodzi odmiana w samej poezji, która najpewniejszym bywa znamieniem wiekowego usposobienia ludów (Mickiewicz V: 186).

Jednocześnie autor zdaje się przekonywać, że każda kultura narodowa przechodzi w swoim rozwoju przez etapy innych kultur narodowych, dążąc do własnego przeznaczenia. Wydaje się, że poeta pisze swój krytycznoliteracki manifest w imię tak różnicy narodowej, określającej charakter twórczości literackiej, jak i koncepcji wielkiej całości kultury, powstającej z jej narodowych fragmentów, oraz aktualności piśmiennictwa, odpowiadającego na wyzwania nowych czasów i zrywającego z imitacją wzorców francuskich.

Różnica narodowa pojawi się w myśli Mickiewicza na dobre w związku z upolitycznieniem jego dyskursu w latach trzydziestych - choć i wtedy twórca nie zarzuci wspomnianej wizji całości - i, co oczywiste, będzie ona związana głównie z narodowością polską, z dążeniem do ocalenia jej tożsamości w momencie, w którym ta była w szczególny sposób zagrożona. Do tej kwestii jeszcze powrócę.

Filomaci w pismach Mickiewicza znajdują wszakże swoje imagologiczne lustro, mające uniwersalistyczny charakter - choć później będzie ono naznaczane partykularnym stygmatem - jakim jest wyobrażenie o starożytności, o antycznym Rzymianinie i zwłaszcza Greku. Sprawa ta jest znana (zob. Witkowska 1998: 123 i n.). Bez wątpienia można w niej dostrzec wpływ tradycji I Rzeczypospolitej i XVIII-wiecznego oraz romantycznego neohellenizmu, a także wiodącej do Wielkiej Rewolucji 
Francuskiej tradycji nowoczesności, początkowo współistniejących bezkonfliktowo, by następnie ujawniać swój potencjał agoniczny, co doprowadzi także do wyodrębnienia różnych obszarów tych tradycji, nabierających zresztą w dyskursie Mickiewicza rozmaitych, zmieniających się w zależności od potrzeb, znaczeń.

Początkowo poeta nie różnicuje obrazów antyku - pozwala mu na to wizja tego, co dawne, jako źródła cnót utraconych następnie w historii. Takie różnicowanie pojawia się we wspomnianej Przemowie, kiedy to wyraźnie Grecja okazuje się ważną tradycją romantyzmu, źródłem paradygmatu oryginalności i narodowości (sic!), wzorem umiłowania wolności, wiąże się ponadto $\mathrm{z}$ formułą piękna klasycznego i pełnego człowieczeństwa, spełniającego się w poszukiwaniu prawdy:

[...] Grecy, długo swobodni, weseli, życie publiczne wiodący, czystą narodowością w całej mocy przejęci, największych cnót liczne przykłady mający, nie mogli nie kształcić się moralnie w wysokim stopniu; kształcili więc drugi oddział władz, które łączą się w charakter moralny. Na ostatek umysły greckie, podniesione, ciekawe, wytrwałe, wcześnie poszukiwać zaczęły prawdy; ćwiczyły się nieustannie rozumowaniem, rozmaitą w nim a najczęściej oryginalną postępując drogą; tym sposobem obudzał się duch filozoficzny, nawykano myśleć porządnie i głęboko, czyli tym sposobem kształcił się, wzmacniał i ustalał rozsądek (Mickiewicz V: 187).

W opozycji do Grecji poeta sytuuje dziedzictwo rzymskie, którego twórczość uosabia wtórność wobec wzorców greckich oraz elitarność, oddalenie od życia ludu.

Grecja w dyskursie Mickiewicza - i szerzej - romantyków (Kalinowska; Kuziak 2012) - to z jednej strony Grecja mitu helleńskiego (estetycznego, antropologicznego i politycznego) wypracowanego przez Niemców (pojawia się on na przykład u tak cenionego przez polskiego poetę Schillera), z drugiej - to Grecja walk wolnościowych przełomu XVIII i XIX wieku, rozpropagowanych między innymi przez również ważnego dla polskiego poety Byrona:

Ojczyzno mężów nieśmiertelnej chwały!

Każda dolina, każdy wierzch twej skały,

Jakże pamiętne! Bo każde z nich było

Kolebką swobód lub sławy mogiłą.

Arko potęgi! Dziś, czyliż tak mało,

Czyż tylko tyle po tobie zostało? -

Wstań, niewolniku podły, wstań na chwilę [...].

(Mickiewicz II: 162)

Oba te obrazy pozwalają Mickiewiczowi myśleć o swojej współczesności, drugi - w szczególny sposób o losie Polski, i to nie tylko w związku z wizją walk niepodległościowych. Polscy romantycy przejęli bowiem wizję Grecji podbitej przez 
słabszy kulturowo Rzym i podbijającej go cywilizacyjnie, by rozpoznawać w jej kontekście relacje polsko-rosyjskie i w ten sposób diagnozować relację upodrzędnionego narodu z potężnym hegemonem.

Wypada wszakże zauważyć, że niebezpieczne dla Polaków lustro imagologiczne, jakim była Rosja, komplikuje możliwość przeglądania się w lustrze greckim. Otóż w prelekcjach paryskich, Mickiewicz z jednej strony rozwija paralelę grecko-słowiańską, eksponującą pierwotność obu ludów i związane z tym wartości, z drugiej - dziedzictwo greckie okazuje się splecione z dziedzictwem bizantyjskim. Krytyczna wersja ujęcia greckiej kultury pojawiła się już w Księgach, w których poeta zwracał uwagę na jej racjonalizm: „[...] bo Grecja, matka filozofów, umarła i leżała w grobie, aż zapomniała o wszystkich naukach, a kiedy stała się prostakiem, oto zaczęła ruszać się" (Mickiewicz VI: 20). Wspomniany splot realizuje się dość stereotypowo, w duchu Heglowskich praktyk orientalizacyjnych, i służy do ukazania genealogii despotycznego ducha rosyjskiego (Bizancjum to także przerost formy) (Kuziak 2004). Takie ujęcie oczywiście czyni problematycznym możliwość tożsamościowej identyfikacji z Grecją.

Przedstawiając krytycznie dziedzictwo Bizancjum, Mickiewicz wraca do rzymskiego lustra imagologicznego, krytycznie przedstawianego w Przemowie do Ballad i romansów. Wielką rehabilitację rzymskiego antyku, głównie tego z okresu kształtującego się chrześcijaństwa, przynoszą wykłady lozańskie, w których - w opozycji do Orientu! (i w tym przypadku wypada odnotować ślad Heglowskiego dyskursu orientalizującego) - okazuje się on źródłem cywilizacji europejskiej, jej fundamentalnych wartości. Mickiewicz, formułując swoje zamiary, stwierdza:

Może uda nam się dowieść, że literatura łacińska nie jest tylko jedną z literatur, lecz że tworzy nieodłączną część jednej i jedynej literatury, której pierwsze słowo zostało wypowiedziane u kolebki rodzaju ludzkiego, a ostatnie - to znaczy to, które my nazywamy ostatnim - rozbrzmiewa $\mathrm{w}$ tej właśnie chwili w ustach wielkich pisarzów. Literatury azjatyckie są to tylko gałęzie owego wielkiego drzewa, które wróciły do stanu dzikości. Literatury te, ważne dla filozofa, dla historyka, dla specjalisty, nie są niezbędnie konieczne dla człowieka o zainteresowaniach ogólnych, dla tego, kto uprawia studium humanitatis (Mickiewicz VII: 183-184).

W prelekcjach paryskich łacina zostaje ukazana jako medium wprowadzające do świata kultury Zachodu, świata wolności, sytuującego się w opozycji wobec despotycznego świata Wschodu, wywodzącego się z Bizancjum i tradycji prawosławnej: „, [...] znajomość łaciny otwierała wrota do starożytności rzymskiej i do piśmiennictwa średnich wieków" (Mickiewicz VIII: 109).

Zatrzymajmy się jeszcze przy lustrze imagologicznym o charakterze uniwersalistycznym, jakim jest u Mickiewicza Orient, powiązany z romantycznymi mitami kulturowymi. Poeta traktuje go dość ambiwalentnie. W wykładach lozańskich wpro- 
wadza przeciwstawienie: zacofany i niezmienny Wschód - rozwijający się Zachód. Z kolei w prelekcjach paryskich, nawiązując do wizji pierwotności Orientu jako źródła cywilizacji, wskazuje na paralelę słowiańsko-orientalną (wzmiankuje także o paraleli litewsko-orientalnej), której ślad widać w następującej wypowiedzi, odwołującej się również do paraleli słowiańsko-greckiej: „Kto pragnie przeszłość wyjaśniać przez teraźniejszość, pomniki zaś i księgi przez to, co w człowieku najistotniejsze, przez jego ducha, ten po wyjaśnienie tradycji greckich i indyjskich będzie musiał zwrócić się do tradycji żywej, a jest nią tradycja naszego ludu" (Mickiewicz XI: 257).

Znamienne przy tym, że ukazane tu Mickiewiczowskie lustra imagologiczne mogą ze sobą wspólistnieć $\mathrm{w}$ jednym dyskursie, a nawet $\mathrm{w}$ jednym tekście. Zwracam przy tym uwagę zwłaszcza na te wykluczające się - konstruowana tożsamość polska może być na przykład i grecka, i rzymska (prelekcje paryskie). Dyskurs romantyka poddaje się logice lokalnej, rezygnując z globalnej, panującej nad jego całością. Powstająca mapa tożsamościowa, by użyć metafory Czaplińskiego, staje się w ten sposób wyraźnie niestabilna.

\section{Wschód/Północ, Rosja}

Główny problem imagologiczny Mickiewicza to bez wątpienia Rosja (Mężyński). Mogliśmy już obserwować, jak jej obecność wpływa na inne, ważne dla poety lustra imagologiczne. Od lat trzydziestych XIX wieku poeta zakłada, że głównym motorem historii jest walka idei polskiej i rosyjskiej (Pigoń). Sprawa jednak komplikuje się w prelekcjach paryskich, kiedy twórca ma mówić zachodniej publiczności o Słowiańszczyźnie. Przyjmuje bowiem, że stanowi ona, wprawdzie zróżnicowaną i podzieloną, ale całość. I właśnie jako całość - naznaczoną pozytywnymi cechami, o których wielokrotnie już pisano (a które mają swoje źródło w dyskursie Herdera, przypomnę, charakteryzującego Słowian jako lud wiejski, pełen związanych z tym faktem cnót) - przedstawia ją Zachodowi, niejednokrotnie również kontrastuje ją z Zachodem, który ma być pozbawiony owych cech, znamiennych dla innej, duchowej Europy, jaką stanowią Słowianie (Piwińska).

Jednak wtedy, kiedy Mickiewicz zajmuje się samą Słowiańszczyzną, jej wewnętrzną problematyką, kładzie nacisk na różnice i podziały, zwłaszcza te kształtujące opozycję Polska - Rosja (jej eksponowanie było ważne w perspektywie utrzymania autonomii polskiej tożsamości, konstruowanej przez odróżnianie się od Wschodu). Opozycja ta przyjmuje charakter paradygmatyczny - obejmuje dzieje, kulturę, literaturę - choć pod koniec wykładów nabiera wymiaru dialektycznego, umocowanego w mesjanizmie; przeżywane wspólne cierpienie ma zdaniem Mickiewicza wieść do pogodzenia i solidarnego podjęcia dzieła przemiany Europy. Poeta konstruuje wizję wielkiej całości tradycji europejskiej, w której swoje miejsce ma i Polska, i Rosja (Witkowska 1990). 
We wspomnianej opozycji Polska uosabia duchowość, wolność, cywilizację, Rosja - materializm, despotyzm i barbarzyństwo. Początków kształtowania się takiej Rosji twórca upatruje w średniowieczu; na temat dawnej literatury ruskiej, oddającej specyfikę powstającego ducha narodu, czytamy:

Ruś, najbliższa plemion uralskich, najdawniej w boju z nimi, dwa wieki jęcząca pod
jarzmem Mongołów, w mężnym i cierpliwym wytrwaniu gotowała przyszą swoją
wielkość. Literatura jej starożytna, jakby tknięta strasznym przeczuciem, ma już charak-
ter poważny i smutny. Później religia staje się jedynym węzłem ludności ujarzmionej
przez Tatarów; wszakże sprawa niepodległości narodowej bierze górę. Literatura ruska
owych czasów jest religijna, bardziej jednak monarchiczna. Książę przewodniczy wal-
ce, wszystko odbywa się przez niego i w imię jego; nie widać bohaterów podrzędnych.
Jednostki usuwają się w cień dla sprawy przyszłej niepodległości i jedności państwa
(Mickiewicz VIII: 32).

Trzeba zauważyć, że pierwsza i ostatnia z wymienionych wyżej dystynkcji (duchowość, cywilizacja) okazują się kłopotliwe. Z jednej strony zarzucano Mickiewiczowi, że definiuje polskie rozumienie ojczyzny w kategoriach duchowych, jako coś nieokreślonego. $Z$ drugiej strony on sam mówił też na przykład o mocy duchowej armii rosyjskiej, przeciwstawiając ją słabości polskiej. Z kolei jeśli chodzi o barbarzyństwo, to w relacji Wschód - Zachód Słowiańszczyzna sytuuje się ogólnie po jego stronie; oczywiście chodzi o barbarzyństwo nacechowane pozytywnie - jak podkreśla wykładowca - stanowiące źródło nadziei na odnowienie Europy (Kuziak 2013a). Nadmienię tu tylko, że wyjątkowo w przedmowie do trzeciego tomu poezji (O krytykach i recenzentach warszawskich, 1829) Rosja okazuje się krajem nowoczesnej kultury, a Polska krajem anachronizmów kulturowych - ujęciu takiemu patronuje jednak przyjęta wizja nowoczesnej cywilizacji, zarzucona przez poetę w latach trzydziestych.

Wypada tu podkreślić, że ważnym kontekstem dla Mickiewiczowskiej imagologii słowiańskiej, szczególnie w związku z jej prezentacją Zachodowi, są europejskie praktyki orientalizacyjne związane z wyobrażeniami na temat Słowian. Profesor-poeta zajmuje wobec takiego postępowania wyraźne stanowisko polemiczne, początkowo wyjaśniając i usprawiedliwiając niedostatki cywilizacyjne Słowiańszczyzny, poszukując też jej wkładu w cywilizację, a następnie wprowadzając dyskurs oparty na konstruowaniu wartości wynikającej z braku cywilizacyjnego. Twórca zdaje się też świadom potencjału orientalizacyjnego dyskursu Herderowskiego, który został przyjęty na początku prelekcji paryskich i odrzucony w trakcie ich trwania. W III i IV kursie prelekcji paryskich stara się ukazywać Słowian raczej jako lud związany z transcendencją, odznaczający się mocą, a nie jako lud natury (Kuziak 2013b). 


\section{Europa}

Jak już mogliśmy to obserwować, w prelekcjach paryskich Mickiewicz miał problem z lokowaniem Polski między Wschodem a Zachodem, z jednoznacznym określeniem jej przynależności do jednego z tych obszarów. Wpisanie Polski w krąg Zachodu - związany z dziedzictwem rzymskiego chrześcijaństwa - dokonuje się wtedy, kiedy poeta pragnie ją odróżnić od Rosji. Ale gdy twórca pragnie zaakcentować inność Polski (oczywiście wartościowaną pozytywnie), wpisuje ją w krąg Słowiańszczyzny.

W Przemowie do Ballad i romansów, o czym już była mowa, pojawia się przekonanie, że poszczególne narody przechodzą etapy rozwoju, na których były inne narody, i dopiero $w$ ten sposób wypracowują własną oryginalność. Jednocześnie tekst ten inauguruje $u$ Mickiewicza romantyczny dyskurs oryginalności, wymierzony zwłaszcza przeciw naśladowaniu literatury i kultury francuskiej; filomaci wszakże pragną być nowoczesnymi Europejczykami, wzorcem dla nich zdają się jednak głównie Niemcy i Anglia, o czym świadczą lektury i konstruowane projekty (widać w nich jednak także obecność myśli Jana Jakuba Rousseau).

Lata trzydzieste upływają Mickiewiczowi pod znakiem dystansowania tożsamości polskiej od obrazu narodów Europy Zachodniej. Dokonuje się to za pomocą konstruowania i umacniania własnej tradycji, zagrożonej tak na emigracji (wobec, jak pisała Zofia Stefanowska, „żywiołów obcych”, zob. Stefanowska 2001), jak i w kraju. Przyczyn owego dystansowania trzeba szukać w rozczarowaniu Europą i jej reakcją na powstanie listopadowe w Polsce. W liście do Lelewela z 1832 roku poeta pisze o liberalnej i kapitalizującej się Francji, rozwijającej cywilizację materialistyczną i stawiającej na wolność indywidualną (głównie bogacenia się), a w efekcie obojętnej na walkę Polaków, których misją powinno stać się głoszenie nowej ewangelii Europie.

Skrajnym przykładem negatywnego dyskursu imagologicznego dotyczącego państw europejskich są Księgi, pojawia się on również w publicystyce „Pielgrzyma Polskiego". Mamy do czynienia ze zbiorem negatywnych, krytycznych stereotypów, pozwalających na zasadzie okcydentalizacji (pojmowanej jako rodzaj orientalizacji zwróconej w kierunku Zachodu, zob. Buruma, Margalit 2005) konstruować idealny obraz polskości. Rzecz w tym, że w istocie obraz ten pasożytuje na praktykach orientalizacyjnych, tylko z odwróconym wektorem wartości, dzięki czemu, jak już wspomniałem, braki cywilizacyjne okazują się zjawiskiem pozytywnym, świadczącym o szczególnej moralności i duchowości, o zdolności do poświęcenia, cierpienia i zmieniania historii. Oto przykład takiego dyskursu:

Albowiem Anglia i Francja są jako Izrael i Juda. Jeśli tedy posłyszycie liberalistów swarzących się o dwie Izby, i o Izbę dziedziczną, i o Izbę wybieralną, i o sposób wybierania, 
i o zapłatę dla króla, i o wolność druku, nie dziwujcie się mądrości ich, jest to mądrość starego zakonu.

Są to Faryzeusze i Saduceusze, którzy kłócą się o tref i o koszer, a nie rozumieją, co to jest kochać i umrzeć za prawdę (Mickiewicz VI: 48).

Sytuacja, przynajmniej częściowo, zmienia się w latach czterdziestych, kiedy Mickiewicz w prelekcjach paryskich konstruuje odmienny od dotychczasowego obraz Francji, już nie nowoczesnej demokracji liberalnej - choć takie wzmianki na jej temat jeszcze pojawiają się w wypowiedziach twórcy - ale najstarszej córy Kościoła, państwa inicjującego nową epokę zbliżenia i pojednania ludów, epokę wolności; w końcu - członka koalicji polsko-rosyjsko-francuskiej mającej przeprowadzić rewoltę odnawiającą Europę. Czytamy na przykład o odnowieniu francuskiego ducha rewolucyjnego:

Geniusz ten [francuski - M.K.] dokonał przewrotu w świecie moralnym: ruszył z posad wszystkie idee o zasięgu lokalnym, wszystkie zapatrywania narodowe, prąc je przed sobą lub pociągając za sobą. Potem je porzucił! Dla tych idei, dla tych zapatrywań przyszedł nareszcie czas, że rozeznały się i wzajemnie się porozumiały; dziś szukają swego przewodnika, wodza, szukają waszego geniuszu (Mickiewicz XI: 492)

\section{4. Żydzi}

W prelekcjach paryskich pojawia się ponadto kolejne lustro imagologiczne, jakim jest obraz Żydów - w świetle Ksiag, jak mogliśmy to obserwować, przedstawianych negatywnie (zgodnie ze stereotypami ekonomicznymi), w wykładach nabierających pozytywno-ambiwalentnych znaczeń. Mickiewicz mówi o Żydach, konstruując przekaz mesjanistyczny, jak również omawiając sytuację Polaków, narodu żyjącego $\mathrm{w}$ diasporze, scalanego posiadanym posłannictwem. Paralela polsko-żydowska powstaje $\mathrm{w}$ prelekcjach $\mathrm{w}$ ramach procesu poszukiwania języka i tożsamości słowiańskiej (polskiej). Twórca, jak już wspomniałem, był świadom orientalizującej mocy dyskursu Herderowskiego - a w każdym razie nabywał taką świadomość, gdyż dyskurs ten stanowił punkt wyjścia jego wykładów - naznaczającego Słowian cechami pozytywnymi i zarazem eksponującego ich niezdolność do politycznej autonomii. Ta świadomość prowadzi do wypracowania mesjanistycznego języka mocy. Znacząca jest krytyka, którą twórca formułuje pod adresem Nieboskiej komedii Krasińskiego:

Mówiłem już, że dramat ten jest na wskroś narodowy. Autor dotknął tu wszystkich zagadnień mesjanizmu polskiego. Wyłożyliśmy je już w roku zeszłym. W dra- 
macie wprowadził lud izraelski, lud słowiański [...], ale zarazem ujął fałszywie cechy wszystkich tych typów narodowych. Dopuścił się, można powiedzieć, występku narodowego, zniesławiając charakter Izraelitów: przedstawia lud izraelski jako czyhający jeno na sposobną chwilę, by zniszczyć szlachtę i chłopów, by dokończyć zagłady chrześcijaństwa. [...]. Są niewątpliwie wśród tego ludu sekty posuwające nienawiść chrześcijaństwa aż do krańcowości, podobnie jak wśród gminu znajdą się jednostki mogące przemawiać językiem owych klubów lokai i rzeźników, wprowadzonych do poematu; nie można wszakże w ten sposób osądzać ogółu ludu. Nie należy tak lekkomyślnie tłumaczyć wyroków Opatrzności, bo nie jest to bez przyczyny opatrznościowej, że Izraelici od tylu wieków żyją wśród Polaków i że ich los jest ściśle związany z losem narodu polskiego (Mickiewicz XI:109-110., podkr. w tekście).

Tym razem Mickiewicz występuje przeciw stereotypizacji Żydów jako wrogów chrześcijaństwa, akcentując tajemniczy splot losów narodu polskiego i żydowskiego, ujawniający łączącą je mesjanistyczną paralelę.

Dyskurs judaistyczny (tak go tu nazwę), jak pokazał to Nietzsche, niesie ze sobą potencjał resentymentu, podobnie jak Herderowski dyskurs słowiański. Mickiewicz wszakże z jednej strony kładzie nacisk na wpisaną weń formułę mocy - cudu, który może dokonać irracjonalny Bóg Starego Testamentu; z drugiej natomiast stwierdza, że Polacy wywodzą się z tradycji nowotestamentowej, którą rozwijają, gdyż głoszą ewangelię odnoszącą się do życia politycznego narodów.

\section{Podsumowanie}

Jak podsumować coś, co u Mickiewicza stanowiło niezakończony i być może niekończący się proces (wypadałoby tu jeszcze przynajmniej wspomnieć o eksponowanym przez twórcę w 1848 roku zbliżeniu słowiańsko-włoskim)? Bez wątpienia poeta korzystał ze słownika imagologicznego epoki, z jego obrazów, stereotypów i zasad ich konstruowania. Daleko twórcy wszakże do rozbudowanych charakterystyk narodów, jakie dali na przyklad Pani de Staël czy Heinrich Heine - wyjątkiem, co oczywiste, są obrazy Słowian, zwłaszcza Polaków i Rosjan, pojawiające się w prelekcjach paryskich.

Imagologia potrzebna jest Mickiewiczowi między innymi (szczególnie?) do konstruowania dyskursu polskiej tożsamości - w grze utożsamień i różnicowania - ukierunkowanego na wytworzenie jej mocnej formuły. Znamienne przy tym, że poeta projektuje ową tożsamość jako powstającą w zgodzie z zasadą ",arki przymierza", łączącej różne, nierzadko heterogeniczne, elementy. Powstający w ten sposób dyskurs tożsamościowy okazuje się, jak pisałem, niestabilny, zmienny, poddany logice lokalnej czy różnym, nierzadko sprzecznym logikom, związanym głównie z ideologią i polityką. Znakomitym przykładem są wyobrażenia poety na temat 
Francji, ujawniające związane z tym krajem nadzieje i rozczarowania (w latach trzydziestych te drugie, w czterdziestych - pierwsze).

Praktykowane przez Mickiewicza konstruowanie tożsamości polskiej, w którym ważną rolę odgrywa imagologia, przypomina o rozważaniach Homiego Bhabhy na temat powstawania narracji narodu. Otóż, jak powiada badacz:

W procesie powstawania narodu jako narracji pojawia się rozszczepienie pomiędzy ciągłą, kumulatywną czasowością pedagogiczności a powtarzalną, nawracającą strategią performatywności. W wyniku tego procesu rozszczepienia dwuznaczność pojęć w nowoczesnym społeczeństwie staje się miejscem pisania narodu (Bhabha 153).

Wypadałoby więc $\mathrm{w}$ związku z rozpoznaniem Bhabhy mówić o zderzeniu w myśleniu Mickiewicza pedagogicznej narracji narodu, scalającej pod znakiem metafory organicystycznej "wiele w jedno" i zarazem wykluczającej to, co „obce” (przykładem może być też Pan Tadeusz) - z mechanizmami performatywności, odsłaniającymi wewnętrzną heterogeniczność narodu.

\section{BIBLIOGRAFIA}

Anderson, Benedict. Wspólnoty wyobrażone. Przeł. Stefan Amsterdamski. Kraków: Znak, 1995.

Bhabha, Homi K. Miejsca kultury. Przeł. Tomasz Dobrogoszcz. Kraków: Wydawnictwo UJ, 2010.

Buruma Ian, Margalit Avishai. Okcydentalizm. Zachód w oczach wrogów. Przeł. Adam Lipszyc. Kraków: Universitas, 2005.

Czapliński, Przemysław. Poruszona mapa. Wyobraźnia geograficzno-kulturowa polskiej literatury przełomu XX i XXI wieku. Kraków: Wydawnictwo Literackie, 2016.

Fanon, Frantz. Wyklęty lud ziemi. Przeł. Hanna Tygielska. Warszawa: PIW, 1985.

Gellner, Ernest. Narody i nacjonalizm. Przeł. Teresa Hołówka. Warszawa: PIW, 1991.

Hobsbawm Eric, Ranger Terence, red. Tradycja wynaleziona. Przeł. Mieczysław Godyń, Filip Godyń. Kraków: Wydawnictwo UJ, 2008.

Kalinowska, Maria. Grecja romantyków. Studia nad obrazem Grecji w literaturze romantycznej. Torun: Wydawnictwo UMK, 1994.

Krasuski, Jerzy. Obraz Zachodu w twórczości romantyków polskich. Poznań: Dom Wydawniczy Harasimowicz, 2004.

Królikiewicz, Grażyna. „Z dziejów romantycznej idei narodu”. Rocznik Komisji Historycznoliterackiej 28 (1992). S. 67-88.

Kuziak, Michał. „Przemiany koncepcji narodowości w prelekcjach paryskich Mickiewicza” Ruch Literacki 5 (1999). S. 517-523.

Kuziak, Michał. „Bizancjum Mickiewicza (Na podstawie „Literatury słowiańskiej”)”. Bizancjum - Prawosławie - romantyzm. Tradycja wschodnia w kulturze XIX wieku. Red. J. Ławski, K. Korotkich. Białystok: Wydawnictwo UwB, 2004. S. 339-352. 
Kuziak, Michał. „Brodziński, Mickiewicz, Mochnacki: Der Alteritätsdiskurs der polnischen romantischen Kritik. Ein Erkundungsversuch". Romantik und Geschichte. Polnisches Paradigma, europäischer Kontext, deutsch-polnische Perspektive. Hrsg. A. Gall, T. Grob, A. Lawaty, G. Ritz. Wiesbaden: Harrassowitz Verlag, 2007. S. 173-183.

Kuziak, Michał. „Grecja - Słowiańszczyzna - Polska. Romantyczna paralela”. Filhellenizm w Polsce. Wybrane tematy. Red. M. Borowska, M. Kalinowska, K. Tomaszuk. Warszawa: WUW, 2012. S. 294-328.

Kuziak, Michał. „The Slavic Barbarian in Adam Mickiewicz's Paris Lectures”. Rocznik Komparatystyczny 4 (2013a). S. 11-24.

Kuziak, Michał. „Mickiewicz postkolonialnie (I). Słowiański głos w prelekcjach paryskich”. Inny Mickiewicz. Gdańsk: Słowo/obraz terytoria, 2013b. S. 119-134.

Mężyński, Kazimierz. Rosja w wykładach paryskich Mickiewicza. Poznań: PTPN, 1938.

Nawarecki Aleksander, Mytych-Forajter Beata, red. Wykłady lozańskie Adama Mickiewicza. Katowice: Wydawnictwo Uniwersytetu Śląskiego, 2006.

Leerssen, Joep. „Imagology: History and Method”. Imagology. The Cultural Construction and Literary Representation of National Charakters. A Critical Survey. Ed. M. Beller, J. Leerssen. Amsterdam New York: Rodopi B.V., 2007. S. 17-32.

Mickiewicz, Adam. Dzieła. Red. J. Krzyżanowski. T. 1-16. Warszawa: Czytelnik, 1955.

Pigoń, Stanisław. „Dramat dziejowy polsko-rosyjski w ujęciu Mickiewicza”. Poprzez stulecia. Studia z dziejów literatury i kultury. Wybór i oprac. J. Maślanka. Warszawa: PWN, 1984. S. 216-234.

Piwińska, Marta. „Prelekcje o Polsce dla Zachodu. Mickiewicz - Miłosz”. Mickiewicz. W 190-lecie urodzin. Red. H. Krukowska. Białystok: Dział wydawniczy filii UW, 1993. S. 377-396.

Stefanowska, Zofia. „Mickiewicz «śród żywiołów obcych»”. Próba zdrowego rozumu. Studia o Mickiewiczu. Warszawa: Rytm, 2001. S. 304-334.

Wellek, René. „Kryzys literatury porównawczej”. Przeł. Ignacy Sieradzki. Pojęcia i problemy nauki o literaturze. Wybór i przedm. H. Markiewicz. Warszawa: PIW, 1979. S. 392-403.

Witkowska, Alina. „Mesjanistyczne tajemnice przeznaczeń w prelekcjach paryskich Adama Mickiewicza". Rocznik Towarzystwa Literackiego im. A. Mickiewicza 25 (1990). S. 91-97.

Witkowska, Alina. Rówieśnicy Mickiewicza. Warszawa: Rytm, 1998. 